\title{
Correlation between Nutritional Status of Pregnant Mothers and Low Birth Weight in the Surakarta Hospital
}

\author{
Febri Maryani ${ }^{1}$, Erindra Budi ${ }^{2}$, and $\| k a$ Sumiyarsi ${ }^{2}$ \\ ${ }^{1}$ Postgraduate Student Faculty of Public Health, Universitas Indonesia, Depok, Indonesia \\ ${ }^{2}$ Faculty of Medicine, Sebelas Maret University, Surakarta, Indonesia
}

\section{Abstract}

The delivery data at the Surakarta hospital for the period of February, $20^{\text {th }}$ 2015-April $3^{r d}, 2015$, showed that the incidence of malnutrition of pregnant mothers was $22.5 \%$ and that of infants with low birth weight was $25 \%$. To investigate the correlation between the nutritional status of pregnant mothers and low birth weight at the Surakarta hospital, this study used the case-control approach. Its variables were measured with a baby scale, toward Health Care of Pregnant Women. The samples were collected by using

Corresponding Author:

Febri Maryani

febri.maryani@ui.ac.id

Received: 26 December 2018 Accepted: 23 February 2019 Published: 7 March 2019

Publishing services provided by Knowledge E

(c) Febri Maryani et al. This article is distributed under the terms of the Creative Commons Attribution License, which permits unrestricted use and redistribution provided that the original author and source are credited.

Selection and Peer-review under the responsibility of the $2 \mathrm{nd}$ International Meeting of Public Health 2016 Conference Committee.

\section{G OPEN ACCESS} the quota sampling. Its subjects were 40, namely: 30 infants with average birth weight and ten infants with low birth. The research used the chi-square test. It found that $22.5 \%$ of the mothers had malnutrition, $77.5 \%$ had good nutritional. Also, $25 \%$ of the infants had a low birth, 75\% had a normal. The analysis with Fisher's p-value was 0.029 and OR was 6.5. There was a significant difference between the nutritional status of pregnant mothers and the incidence low birth weight at the Surakarta hospital. The expectant mothers with malnutrition had the probability of 6.5 larger to have infants with low birth weight than their counterparts with excellent nutritional.

Keywords: Nutritional; pregnancy; low birth weight

\section{Introduction}

Nutritional status has a significant role in the human life cycle. Everyone's needs for nutrients are the same; however, the numbers are not the same (Kusharisupeni 2011). The nutritional status of an adult is the result of growth throughout life begins in the womb, infancy, childhood, and puberty. The degree of nutritional status can see from the absence of major dietary problems, such as chronic energy deficiency, Deficiency of lodine, Anemia (Achadi 2011).

Chronic Energy Deficiency (CED) is a deficiency state's energy needs in a long time or chronic, result of an imbalance between intake and expenditure to meet the needs of energy. It can be known with MUAC measurement (Upper Arm) that result $<23.5$ $\mathrm{cm}$. Aside from the MUAC measurement results under normal, CED patients have an imbalance between weight and height as well as less active (Triyanti et al. 2011). 
When someone has a shortage of the required amount of nutrients the body needs, especially for women, she will have an impact throughout its life cycle. If they are pregnant, there is the risk of having a baby with low birth weight (LBW), weight infants $<2.500$ gram. This condition is also confirmed by the results of the study (Hanifah 2009) were obtained, the value of $\mathrm{p}=0.000$.

It needs to get more attention because of low birth weight often experience an increase in infections, susceptible to complications: disorders of the respiratory system, central nervous system disorders, cardiovascular, hematologic, gastrointestinal, renal, thermoregulation, death. Also, it also occurs difficulty in catch-up growth, followed by impaired cognitive function (Achadi 2011).

The Basic Health Research (RISKEDAS) 2013 results showed that the percentage of LBW $10.2 \%$ of total live births. Central Java reached 21.573 cases (3.75\%). Surakarta had as many as 205 cases (2.00\%) of 10.135 live births, and the fact is increased compared with the previous year, 1.8\% (DKK Surakarta 2013).

Also, the Hospital Surakarta in 2014 obtained the incidence of LBW by 170 cases (10.9\%) out of 1559 live births, and these events tend to rise every month (Rekam Medis RSUD Surakarta 2014).

In addition to a high incidence of low birth weight, in our country, the impact of CED on the women of childbearing age is also quite high. Conditions RISKESDAS seen from the data in 2013, it was obtained CED in pregnant women $24.2 \%$ and $20.8 \%$ non-pregnant women (Kementerian Kesehatan 2014). In Surakarta, it showed that pregnant women with CED as many as 497 people (4.55\%) of the target amounted 10.923 pregnant women (Dinas Kesehatan Kota Surakarta 2013).

The incidence of LBW at the Surakarta hospital which has increased every month and the nutritional status of pregnant women affect birth weight infants then it is suggested to research Relationship between Nutritional Status Pregnancy and LBW at The Surakarta hospital.

\section{Methods}

The design of this research study used case-control approach, and it aims to study the relationship between the causes of illness and disease investigated by comparing the case group and the control group based on the status of disease-causing, retrospectively. This research analyzed the relationship between the nutritional status of pregnant women and low birth weight, comparing groups of LBW and not LBW. 


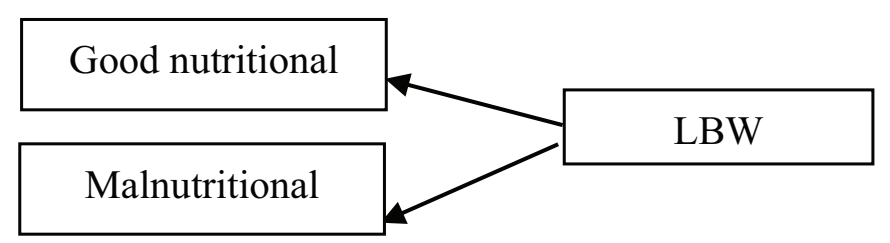

(Group of a case)

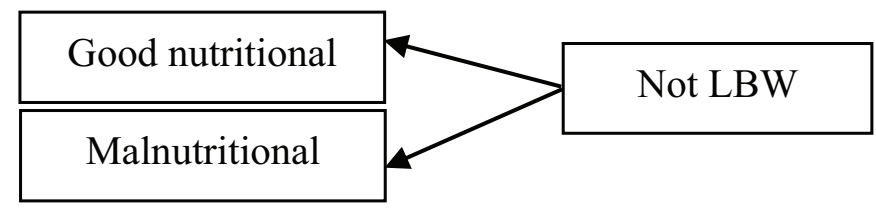

(Group of control)

Figure 1: Design of the case-control.

This research was conducted at room Maternal and Infant Care, at the Surakarta hospital, in December 2014 - June 2015. The total sample consisted of two groups: the control group of 30 subjects, whereas the case group of 10 items. The allocation of issues was by matching. The instruments used were baby scales, MUAC measurement results that had recorded in the KMS Pregnancy. The limit of significance $(\alpha)$ was 0.05 and a confidence interval was $95 \%$.

\section{Results and Discussion}

In the early stages of statistical tests, it was performed with chi-square test and there was one cell which had an expected value $<5$ then used the alternative analysis. The Fisher exact test was shown in the table as follows:

TABLE 1: Crosstab Nutritional Status of Pregnant Women and Low Birth Weight.

\begin{tabular}{|c|c|c|c|c|c|c|}
\hline & \multicolumn{5}{|c|}{ LBW } & Statistic test \\
\hline & \multicolumn{3}{|c|}{ LBW } & \multicolumn{2}{|c|}{ No } & \\
\hline & & & $\%$ & $n$ & $\%$ & \\
\hline \multirow[t]{2}{*}{$\begin{array}{l}\text { Nutrition } \\
\text { Status }\end{array}$} & Mal & 5 & 50.0 & 4 & 13.33 & $\begin{array}{l}\mathrm{p}=0.029 \\
O R=6.5\end{array}$ \\
\hline & Good & 5 & 50.0 & 26 & 86.67 & \\
\hline Total & & 10 & 100.0 & 30 & 100.0 & \\
\hline
\end{tabular}

From the statistical test in table values, it was obtained significance $=0.029$, the $p$ value of $<0.05$, showing that there was a significant difference between the nutritional status of pregnant women and the occurrence of LBW. Odds ratios (OR) for the case and control groups was 6.5 , showing that pregnant women with malnutrition status could experience LBW 6.5 times compared to pregnant women with good nutritional status. 
It could be concluded that pregnant women with malnutritional status could experience LBW 6.5 times compared to pregnant women with good nutritional status. The results of this study was reinforced by research Hanifah (2009), showing that there was a relationship between Upper Arm Circumference (MUAC) maternal and infant birth weight. Eddyman (2011) concluded that there was a significant correlation between maternal nutritional status by size Upper Arm Circumference (MUAC) with birth weight infants. Rukmana (2013) stated that there was a relationship between nutrient intake and nutritional status of pregnant women with baby's birth weight. The hypothesis of this study could be proven or acceptable.

\section{Conclusions}

There was a significant difference between the nutritional status of pregnant mothers and the incidence of infants with low birth weight at The Surakarta hospital. The expectant mothers with malnutrition had the probability of 6.5 higher to have infants with low birth weight than their counterparts with a good nutritional status.

\section{References}

[1] Achadi E. 2011. Gizi dan Kesehatan Masyarakat. pp: 245-53Jakarta: Rajawali Pers.

[2] Kementerian Kesehatan. 2014. Profil Kesehatan Indonesia. Jakarta: Depkes, pp: 889.

[3] Dinas Kesehatan Kota Surakarta. 2013. Profil Kesehatan Surakarta 2012. Surakarta: Dinkes Surakarta, pp: 50-2.

[4] Eddyman W. 2011. Hubungan antara Status Gizi Ibu BerdasarkanUkuran Lingkar Lengan Atas (LILA) dengan Berat Badan Lahir Bayi di RSUD DayaKota Makassar. Jurnal Alam dan Lingkungan. 2 (3): 11-21.

[5] Hanifah L. 2009. Hubungan antara Status Gizi Ibu Hamil dan BBLR di RB Pokasi 2009. Surakarta: UNS. Karya Tulis IImiah.

[6] Kusharisupeni. 2011. Gizi dan Kesehatan Masyarakat. Jakarta: Rajawali Pers, pp:14958.

[7] Rekam Medik RSUD Surakarta. 2014. Rekam Medik RSUD Surakarta. Surakarta.

[8] Rukmana S. 2013. Hubungan Asupan Gizi dan Status Gizi Ibu Hamil Trimester III dengan Berat Badan Lahir Bayi di Wilayah Kerja Puskesmas Suruh, Semarang: UNDIP. Skripsi.

[9] Triyanti, dkk. 2011. Gizi dan Kesehatan Masyarakat. Jakarta: Rajawali Pers, pp: 27581. 